however, must not merely consist of coercive measures against an aggressor nation; they must be a protection against aggression. It is in this respect that economic sanctions fail whether they take the form of an economic and financial boycott of the aggressor or that of a regular blockade. (1) They come too late; they can only be applied as a corrective; they do not protect against aggression. (2) Economic sanctions are notoriously slow in their application. (3) They are a double-edged weapon, striking at international trade and punishing the innocent with the guilty. (4) Economic sanctions are powerless against nations which can, if need be, form selfsufficient economic units, such as the United States to-day and the U.S.S.R. to-morrow. Dr. van der Leeuw contends that an international police force alone would make complete disarmament possible, since it would provide security against aggression, not merely coercion afterwards. Each nation would contribute its quota to the world police and, having done so, would not be further involved.

\section{Old Gaza}

Sur Flinders Petrie's letter to the Times of June 2, announcing that it would not be possible this year to hold the usual exhibition of material from the Palestinian excavations of the British School of Archæology in Egypt, will give rise to much regret. The members of the schnol, Sir Flinders reports, this year have been engaged for the third season in succession in the excavation of Old Gaza (Tell el Ajjul), where the earliest palace, dated at about 3200 B.c., discovered last year, awaited clearance. It now appears that the foundations were laid in a rectangular block about $127 \mathrm{ft}$. from north to south and about $166 \mathrm{ft}$. in length. The buildings enclosed a large square courtyard with chambers on three sides, but with an enclosing wall only on the fourth, or south, side. Egyptian influence is strongly marked in a number of small objects and a finely carved stone head from a funerary jar, which is earlier than any from Egypt. Greater interest, perhaps, is attached to several objects which may point to the place of origin of the Syrian invaders. These were a bronze dagger with raised veins, very similar to one found last year, which is a Caucasus type, and two forms of toggle which belong to the same area. The burial was early, while from a superimposed burial came a scarab which cannot be later than the xith dynasty. South of the palace area massive buildings were uncovered in a sand dune which yielded fragments of painted pottery, similar to that found last year, of which the origin is still obscure, although northern Syria, Armenia or Cappadocia are indicated. The buildings with which this pottery was associated were of the age of the first and second palacesviith and xiith dynasties. Other parts of the Tell have been excavated, yielding nearly two hundred types of pottery, and the family tomb of an Egyptian governor, which indicates a continued Egyptian occupation from the time of Akhen-aten to Rameses II. A second gold torque ear-ring of Irish pattern occurred in an xviiith dynasty level.

\section{Local Archæological Observation in the United States}

USEFUL information relating to local archæological sites and discoveries, which might otherwise be disregarded as unimportant and lost to sight, is being recorded through a system of local correspondents and investigators inaugurated by Science Service (Washington, D.C.). Naturally the information varies considerably in value and interest; but as time goes on, the organisation should serve a useful purpose in preserving data which will assist in determining the character, distribution and relation of the Indian cultures which had become extinct before the days for which records of the tribes are available. An instance in point is afforded by a communication recently received by Science Service from Mr. William E. Baker of Boise City, Oklahoma, who describes Indian ruins on the south bank of the Beaver River, four miles south of Optima, Oklahoma. The ruins are of the type known as 'slab house', being constructed of stone slabs, set on edge. Before the depredations of neighbouring builders, they covered a site of several acres. Their artefacts, flint arrow points, drills, snub-nosed scrapers, and bone implements, are such as have a wide distribution in the Plains, being found in the western half of Kansas, the panhandle of Oklahoma and of Texas. They have also been found at Pecos Pueblo. Mr. Baker differentiates two cultures, partly on stratigraphical grounds. The earlier is characterised by a small arrow point with right-angled notches, which is associated with pottery of the Plains type. In the later the arrow point is large and has diagonal notches, but pottery is absent. The former was probably partly agricultural - a view supported by a suggestion of irrigation and the discovery of kernels of corn-the latter nomadic. This order and association has been found by Mr. Baker over a wide local area while the cultures are related to types described by Dr. W. K. Moorehead on the Arkansas River and Dr. A. W. Kidder at Pecos Pueblo. Mr. Baker suggests that there was a widely distributed semi-agricultural population spread over the Plains before the coming of the Spaniards, when the introduction of the horse made possible a nomadic life dependent on the buffalo.

\section{Oil Reserves and Production}

Some interesting figures of oil reserves and past production to date were given by Mr. V. R. Garfias to the American Institute of Mining and Metallurgical Engineers recently. According to this authority, the proved oil reserves are estimated at more than 24 billion barrels and the world production of oil to date aggregates nearly 23 billions. Of the realised reserves, 61 per cent are located in the American continent, while Russia, Iraq and Persia account for 33 per cent. Science Service of Washington, D.C., states that the American reserves, when compared to the probable future consumption in the United States, will prove inadequate to meet demands for more than a few years, unless there should be a pronounced falling off in demand. It is considered that the Venezuelan, Iraq and Rumanian fields will 